\section{Anatomy of a conflict}

\section{Shepard Krech III}

Archaeological Perspectives on the Battle of the Little Bighom. By Douglas D. Scott, Richard A. Fox, Jr, Melissa A. Connor and Dick Harmon. University of Oklahama Press: 1989. Pp. 309. Hbk $\$ 24.95$.

WHAT more could possibly be said about the Battle of the Little Bighorn that has not been? An event that electrified the country the instant it happened, it continues to excite the imagination. Biographies have been written on the principals involved on both sides - George Armstrong Custer, Crazy Horse and others as have numerous detailed accounts, from both Indian and white perspectives, of the battle itself and the historical circumstances leading up to and following this epic confrontation, on 25 June 1876, between the US Seventh Cavalry and the Sioux and Cheyenne Indians.

There are no lingering significant controversies in the interpretation of this historical record. But because there are different perspectives, and because the production and re-production of history is invariably a cultural, presentist exercise, conflicts persist over the interpretation of details in the voluminous historical archive, which probably will occupy historians well ts, from The authors failed to discover the remains field markers actually were placed over human remains; what the bones of troops reveal about diet, trauma and death; how combatants moved about the battleground; and what firearms were used.

The results of archaeological investigations - metal-detector surveys, shovel and backhoe excavations - are mixed. ments - "the number of bullets impacted in the defence perimeter strongly suggests that the incoming fire must have been heavy" (p. 140). Although plotting distributions leads to a "further clarification" (p. 138) of the positions of the combatants or "correlates well with the historically known combatant positions" (p. 134), it unfortunately adds little to the known historical record.

The most interesting results concern the identification and analysis, on the basis of cartridge cases and bullets, of types and quantities of firearms used by Indians and whites. More than 40 types of guns were used in the battle, and the distribution of types - even of individual weapons - can be derived from signatures that guns leave on bullets and cartridge cases. Even here,

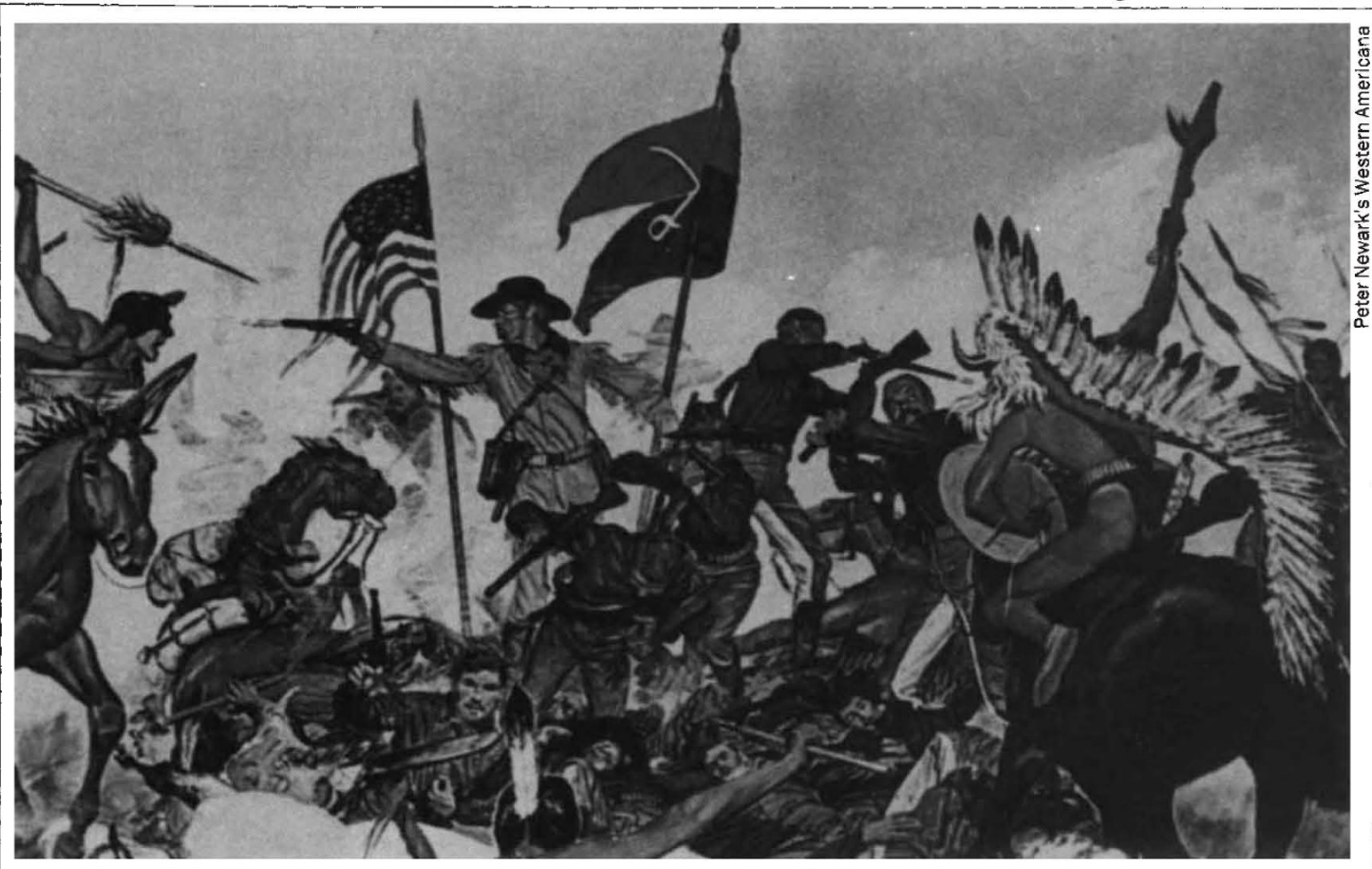

llluminating the past $-\mathrm{H}$. Charles McBarron's painting of Custer's last stand. into the future. Nevertheless, when one | of the last 28 soldiers, but they think they reads on a book jacket that assembled therein is "the most compelling and convincing evidence thus far of what happened on that day in southeast Montana 113 years ago", one can be forgiven for suspecting a publisher's marketing department of hyperbole.

Indeed, the aims of the authors of this book are far more modest, even though at times, it seems, they also are caught up in Little Bighorn hype when they are not actively proselytizing for the revisionist potential of historical archaeology. Grasping the opportunity presented by a grass fire that removed vegetation on the Custer Battlefield National Monument, the authors (of the four, one is a military archaeologist, another an expert on firearms) undertook a comprehensive programme in historical archaeology to determine where 28 soldiers killed in a cul de sac were interred; whether marble battle- now know, by the use of geomorphology and archaeology techniques, where the troopers cannot be and where they are likely to be found. As for the markers, some are improperly placed, not surprisingly because the dead were 'buried' three or four times: the day after the débâcle, the bodies were covered; in 1877 and 1879 , exposed remains were reinterred; and in 1881, disinterment was followed by reburial in a mass grave. Nine years later, marble markers were placed on the battlefield, and the following year a map was prepared. Little wonder there are discrepancies. The bones show ample signs of trauma after death, to which all historians concur and about which, for cultural context, Indian sources are most revealing.

The distributions of cartridge-case, bullet and other artefactual materials on the battleground make interesting figures, despite predictable (and wooden) assess- however, the archaeological record in part corroborates extant archival materials: a list of guns surrendered by the Sioux and Cheyenne in 1877.

Despite their evident enthusiasm for historical archaeology, the authors wisely state that they do not believe it represents "the last work" (p. 11) in the study of the Little Bighorn. Indeed, apart from often being able to corroborate the known historical record, the conclusions that one can draw from this work are limited Similarly, where the historical record is in dispute, the illuminations provided by historical archaeology are few, with one exception: bullet and cartridge-case distributions support Indian, not white, accounts of the battle.

Shepard Krech III is a professor of Anthropology and director of the Haffenreffer Museum, Brown University, Box 1921, Providence, Rhode Island 02912, USA; and editor of the journal Ethnohistory. 